\title{
Mentiras na verdade da República
}

\section{Lies in the truth of the Republic}

Flávio R. Kothe

\section{RESUMO}

A revisão da concepção de verdade implica no questionamento da duplicação metafísica do mundo, que encontra na "República" de Platão uma formulação lapidar, mas tem lá também, na parábola da caverna, uma ficção que permite uma interpretação inversa ao que formulado na argumentação lógica.

Palavras-chave: Verdade; Metafísica; Duplicação do mundo; Mito da caverna.

\begin{abstract}
The revision of the conception of truth implies the questioning of the metaphysical duplication of the world, that has in Plato's Republic a definitive formulation, but has there also, in the parable of the cave, a fiction that allows an inverse interpretation to what is formulated in the logical argumentation.
\end{abstract}

Keywords: Truth; Metaphysics; World duplication; The myth of the cave. 
Se moquer de la philosophie, c'est vraiement philosopher.

\section{Pascal}

\section{NA TERRA COMO NO CÉU}

Assim na terra como no céu: perdidos estaremos enquanto não nos recuperarmos da alienação metafísica. Estamos num país em que a oligarquia nos três poderes tem aparecido cada vez mais como corrupta e mentirosa. Isso não acontece por acaso, tem raízes metafísicas, não somos melhores que outros nisso. Se estas não forem expostas, não serão superadas; explicitá-las não garante cura, pois é mais cômodo ficar preso a elas. Calar é conformar-se; falar, suicidarse. Como se fizer, vai se fazer errado.

A duplicação metafísica do mundo, consagrada pelo cristianismo, pelo romantismo e por movimentos totalitários, é pregada em Platão, especialmente nas falas de Sócrates, que, sob a aparência de filósofo e antissofista, é um declarado missionário de Athon. A lógica do "mito da caverna" é impositiva: quem visitou uma caverna sabe que existe o mundo fora da caverna, portanto existem o céu e seus deuses. Sócrates pretende ser superior aos "sofistas", que são professores pagos e, só por isso, aparecem como grandes mentirosos. Alguém ser pago ou não por uma aula não faz a diferença entre ela ser ou não verdadeira. Platão não foi platônico, mas propiciou o platonismo. Carrega culpa.

A tradição de estudos clássicos costuma passar batido o problema do escravismo dizendo ser anacrônico, para daí se perder em detalhes filológicos (sem ter uma edição crítica histórica confiável) e acaba por endossar posturas reacionárias, ainda que por omissão. Sob aparência de ciência cai em miopia alienada, que não enxerga suas limitações como não vê o que projetou. Sob o distante e antigo, fica presente o imposto pelo presente. Não por acaso Nietzsche e Heidegger foram usados pelo nazismo e o classicismo antigo foi modelo estético para regimes totalitários. Os Estados Unidos se apresentam como democracia, mas são uma plutocracia imperialista, cuja capital foi construída imitando os gregos.

Aristófanes apresentou, em As nuvens, Sócrates como o maior sofista. Isso é mais do que uma piada, é uma tragédia amarga, em que estamos mergulhados ainda. Se "o filósofo" não vive do ensino, de que vive ele? Do trabalho escravo. Como Platão e Aristóteles. Um truque filológico é, então, empurrar o "erro" para um personagem como Sócrates, a fim de preservar o autor Platão. Embora se deva distinguir o que Sócrates diz do que ele pensa, do que Platão pensa sobre o que Sócrates pensa sobre o que Sócrates diz, Platão não é tão inocente. Há omissões e distorções graves. Temos de ler Platão contra Platão para chegar a Platão. Mesmo que na República haja a transição de um Sócrates dogmático para um que parece pensar, esse "progresso" não é acompanhado por uma evolução de Glauco, em geral um coroinha a dizer amém em vez de ser um antagonista. $O$ diálogo é apenas aparente, não há dialogismo.

Na República, as formas de governo decorrem umas das outras por suas características, mas por baixo desse laicismo aparente há a teologia de que só poderá bem governar quem tiver sangue divino: o aristocrata. Sócrates propõe-se criar um Estado mais justo, uma forma de governo que seja capaz de exercer o bem 
comum. Aparece, portanto, repleno de boas intenções: aparenta querer o bem comum, quando de fato pretende, sob a aparência de meritocracia, aperfeiçoar a aristocracia escravista de sangue.

Nem todo aristocrata tem vocação e jeito para o poder. $\mathrm{O}$ filho mais novo pode ser mais hábil do que o mais velho, como se mostra nos filhos de Édipo ou de patriarcas bíblicos. O mundo das ideias é proposto como contrapartida ao "mundo das cópias", para "resolver" de modo mágico um impasse para o qual o autor parecia não ter a solução, ou seja, sob a aparência de como se pode chegar à identidade de coisas diversas, ver como se escolheria o mais hábil dos herdeiros senhoriais para garantir o domínio de sua classe.

A Igreja Católica implantou esse sistema, e ele funciona há milênios, sem que se questione seu fundamento: qual é o mérito do mérito? Quem questionou isso foi reprimido, pagou com exclusão, tortura e morte. Platão aparenta buscar o que é justiça, já que não basta a resposta de que ela é a vontade do mais forte, mas pressupõe como justas a escravidão e a aristocracia de sangue. Aparenta propor a melhor forma de governo, já que todas as existentes são problemáticas, mas não problematiza a sua.

Ao contrário da crença democrática hodierna, dominada por pressupostos teológicos cristãos de igualdade, Sócrates não está convencido de que a melhor forma de governo seja a democracia, pois ela é para ele uma feira livre em que todos gritam, achando que podem dar palpite em tudo, especialmente no que não entendem. Nela o político promete mundos e fundos para ascender ao poder, no qual não vai cumprir o prometido. A democracia leva à manipulação demagógica. No poder, o demagogo vai ficando cada vez mais sozinho, tendendo a locupletar-se: ele é o principal beneficiário do seu povo.

Frustradas as expectativas, ele só se mantém no governo pela força, e pela força é que acaba sendo apeado. Tem-se então a ditadura militar. Os militares no poder vão tomando gosto pelas benesses do poder, ficam se regalando e corrompendo, privatizam o bem público e acabam perdendo as virtudes militares. Provocam assim uma rebelião popular que, ao ter êxito, restabelece a democracia, reiniciando todo o ciclo perverso.

Para romper esse círculo, considerado vicioso devido aos enormes desgastes e sofrimentos do seu moinho de carne, Sócrates propõe outra forma de governo: a aristocracia do mérito. Ela diferiria da aristocracia do sangue, pois o filho de um homem de ferro poderia ser um homem de ouro, assim como o filho de um homem de ouro poderia ser apenas de ferro. Esse modelo já existia sob a forma da teocracia, em que a casta sacerdotal governava, como aconteceu na antiga Grécia e no Egito.

A Igreja Católica adotou essa forma de governo, com a variante única de ter a monarquia eleita, em que os pares escolhem seu príncipe, dizem que iluminados pelo Espírito Santo, mas nem todos conseguem sintonizar bem a voz do alto. O celibato religioso foi imposto para enriquecer a instituição, seja por herança e seja evitando gastos com a família, mas resolveu em parte a questão do nepotismo (podem ocorrer “sobrinhos espirituais”). O porta-voz de Platão, 
Sócrates, não discute se o homem de ouro não teria a propensão de fazer seus filhos aparecerem como homens de ouro. Não garante que um homem de ouro poderia t er nascido escravo, mas o "mito da caverna" nos indicia uma resposta: não há homem de ouro parido por escrava.

\section{Menos iguAis}

Em Eurípides, nas Troianas, mulheres da aristocracia vencida lamentam ter sido reduzidas a escravas, mas dentro da concepção de que quem nasceu livre e tem sangue azul não está predestinado a ser escravo. Nas Leis, Platão, ao falar da posição da mulher no casamento, toca por analogia na questão da escravidão, no sentido de que nenhuma pessoa sensata iria duvidar da legitimidade do escravismo, do direito de um povo escravizar os vencidos (assim como, podemos depreender, cabia aos patriarcas submeter as mulheres). Ele recomendava equilíbrio no trato com escravos: nem despótico a ponto de provocar vingança contra familiares, nem íntimo a ponto de se tornar dependente. Ele tinha, portanto, noção da "política" nesse setor, o que ele ignora na República.

Reiteradamente tem-se nele a assertiva de que os "sofistas" são indecentes e inconfiáveis na argumentação porque "vendem conhecimentos”, ou seja, são professores assalariados. A contrapartida é um "mestre" que não precisa ser pago para ficar lecionando. Ora, quem sustenta esse mestre? Que mestre é esse que não precisa de dinheiro para sobreviver? Qual seu segredo? Ora, simples: já que o Estado não intervém, tem escravos que o sustentam, ele vive, e bem, às custas de escravos: como professor, prepara novas elites de comando.
Hoje, a "escravidão” se disfarça de salário mínimo, empreitada e diária, que são formas mais baratas do que manter escravos permanentes. Por essa semelhança estrutural, tendemos a não ver o que mais deveríamos. Sócrates é o sofista maior, e sobre ele repousa a cultura ocidental. Aparece como representante da verdade, quando é um ideólogo do escravismo. Não agrada falar do que mais dói.

Platão chega a aventar, através de Sócrates, que um escravo poderia ter "alma”, à medida em que ele é capaz de intuir princípios de proporção geométrica e matemática, já que sua "psiquê" poderia ter contemplado o mundo das ideias. Aristófanes resolveu isso com uma risada: quando escravos disputam o direito de serem levados para os Campos Elísios, diz que eles não têm dinheiro, não podem pagar o transporte. Mesmo que tivessem "alma”, seu destino seria ficar vagando: almas penadas pelo mundo (conforme haviam feito em vida). No Direito Romano, um escravo equivalia a um cavalo ou a um boi: seu dono podia bater nele, podia até matá-lo, que não seria responsabilizado por crueldade ou assassinato.

Platão não leva adiante, contudo, a suposição de o escravo ter alma: o cristianismo deveu seu sucesso à democratização da imortalidade antes reservada a deuses e raros descendentes. Ao preço de três gotas e palavras mágicas, cada um queria a sua. Na perspectiva antiga, somente as famílias nobres tinham um ascendente divino e, portanto, lhes corria nas veias um "sangue azul”, que lhes dava superioridade social, a capacidade de realizar feitos históricos, dandolhes o direito de ter governança, gado e gente. Aquilo que os tornava superiores à média dos homens livres era terem uma anomalia, uma 
ruptura com a ordem natural das coisas, o que levava também ao seu final trágico, pelo qual se corrigia a "aberração". O gênio virou nobre espiritual moderno.

O Sermão da Montanha é a inversão da ética dos patrícios. Cristo gosta de débeis mentais (pobres de espírito), pescadores que não tinham sequer terra, mulheres adúlteras, prostitutas, doentes e defuntos. Ele não gostava de gente inteligente, forte, organizadora, inventiva, não gostava de artistas, cientistas, estadistas, empresários. Quanto pior, melhor. Ele era tão perverso na sua inversão quanto era o patriciado na arrogância.

Hegel, no final da introdução à História da Filosofia, admite que a escravidão tenha estado subjacente à produção de filosofia e arte em Atenas, mas diz que a ele só interessava o resultado. Este, porém, era determinado pelas condições de produção, ele está no cerne do que se propõe como filosofia: não é um vetor que possa ser descartado. Se a verdade é a percepção do objeto em suas múltiplas determinações, esse fator é a condição de subsistência da produção.

Nietzsche admitia que, na história, a escravidão tinha sido a condição possibilitadora da produção artística e filosófica, e até falava da "metamorfose do escravo", ou seja, que o trabalhador moderno, do século XIX, era um escravo mais barato que um escravo, pois este precisa ser comprado, cuidado e mantido, enquanto o assalariado ou o diarista são contratados para determinadas tarefas, por um preço que em geral é menor do que o de um escravo, com a vantagem de o patrão poder se livrar dele mais facilmente. Ter um mau escravo é ter um péssimo casamento.
Lukács, ao falar no "irracionalismo na filosofia alemã”, propôs que a escravidão havia deixado de ser condição necessária para a produção intelectual, já que a tecnologia proporciona uma abundância de produção que permite sustentar grupos sociais que se dedicam à produção intelectual. Quanto maior a tecnologia, maior pode ser, contudo, a exploração do trabalho e a manipulação das mentes. Benjamin propôs que a produção artística faria parte das forças de produção e, como tal, teria uma função inovadora nas relações sociais: a burguesia percebeu isso melhor que ele.

Adorno achou que a condição de mercadoria degradava a obra de arte. Para o artista e o intelectual, no entanto, conseguir que suas obras sejam adquiridas significa que alguém decidiu trocar um tempo do seu trabalho pelo tempo deles. Isso envolve uma valorização do produto e não apenas a sua degradação. O pior para quem produz é não conseguir vender. Dizer que a arte tem função no capitalismo por não ser útil é não perceber quão útil é a estetização para a dominação social. Basta ver os santinhos que se vendem nas épocas de eleição e os capetas que estão por baixo.

Com a industrialização capitalista, o direito de comprar e vender no mercado e a semelhança nas condições de trabalho, bem como a crença cristã numa comunidade fundamental, impuseram a igualdade como paradigma. Ela não é, contudo, um valor apenas necessário à mecânica do mercado. Foi herdada pela revolução socialista, mas já é um tema central na Grécia antiga. Esse princípio vem sendo lido como igualação do desigual, mas pode ser interpretado também como respeito à desigualdade do desigual. Igual nos humanos é serem desiguais e 
finitos (com a pretensão de serem infinitos). Crêse que todos devam ter iguais oportunidades. Mesmo que essa crença seja praticada, quem é desigual não aproveita igualmente oportunidades iguais. E quem mais aproveita pode se tornar um malandro melhor treinado.

Se a estrutura social continua sendo de uma minoria que vive bem às custas do trabalho da maioria, pode-se entender que não se tenha desenvolvido uma sensibilidade para a desigualdade. Os filósofos tendem a estar mancomunados com a exploração de classe e não se preocupam com isso. A inovação filosófica moderna deu-se, porém, quando a noblesse de robe, ou seja, a burguesia esclarecida, pôs-se a pensar. Heidegger, por exemplo, discute vários aspectos do mito da caverna, mas não considera o problema social subjacente. Não é problema para ele. E ele era mais inteligente.

\section{MÉRITO}

No Hipias Maior como em outros textos, Platão afirma, categórico, que a arte se volta apenas para os sentidos da visão e da audição. Essa proposição foi repetida por filósofos como Solger e Hegel, mantendo-se inquestionada até hoje nas universidades. A divisão de obras feitas pelo homem entre arte e artesanato é proposta como uma divisão sensorial: haveria dois sentidos superiores, espirituais, e três inferiores, corporais. Ora, aqueles são corporais assim como estes são também “espirituais”. Há algo mais nesse erro.

O que ia para o consumo da boca, do nariz e da pele era gerado por trabalho feito por escravos - roupas, sandálias, alimentos, massagens, aromas -, enquanto pinturas e esculturas, música e peças teatrais, casas e praças eram feitas por trabalhadores livres. A diferença de corpo e alma decorria da diferença do valor social do labor. Platão achava que na língua grega seria inapropriado dizer uma bela comida, um belo perfume, mas na linguagem brasileira isso já não soa tão estranho, só que para ele não se poderia filosofar senão em grego. Não há por que a língua grega deva ser parâmetro mundial, conforme impera na lógica até hoje. Não está no Gênesis que ela tenha sida a língua adâmica.

Subjacente a isso deve haver algo mais. A obra de arte é mais significativa que o artesanato, mesmo quando este seja adornado. A significação da obra de arte tem sido vista como expressão da ideia, a manifestação da verdade, a revelação da alétheia. Ela é, porém, algo mais do que um agente transmissor de algo cuja validade pretende estar fora dela. De qualquer modo, fica impresso que o "escravo" não teria nada a dizer. E isso se confirma no livro VII da República.

Outro ponto central que não é discutido na Politeia é o que se entenderia por mérito. O que a uns parece mérito, conforme determinado paradigma, pode ser visto como demérito ou carência de méritos segundo outros paradigmas. A correta aplicação parece verdadeira para quem não vai além deles. Juízes julgam, conforme paradigmas, apenas o que consta nos autos do processo, mas quem garante que tudo o que é atinente ao caso consta dos autos e quem julga os paradigmas, a leitura que fazem os juízes? Na Igreja essa questão é reprimida pelo voto de obediência, pela propaganda sacralizadora, pela crença no 
absoluto. Até mesmo Freud disse, ao querer a expulsão de jovens brilhantes da sociedade psicanalítica, que preferia a instituição aos gênios. A universidade brasileira é uma instituição marcada pela perseguição e discriminação contra o talento.

Não discutir o mérito do mérito não é ocasional, mas determinado pelo movimento ideológico subjacente à obra, que leva a olvidar o sentido de verdade como "alétheia", como um desvelamento, para optar pela "correção conforme paradigmas”. Há um paradigma básico na "casa” que é a caverna e que não é questionado. Nessa moradia coletiva tem-se a síntese alegórica da sociedade antiga. Sob a aparência de iluminar, tem-se antes um obscurecimento do que a busca radical da verdade. A atmosfera é sufocante.

Seja quando Sócrates propõe que há um mundo das ideias, anterior a tudo, do qual a realidade seria uma "cópia", seja quando "se redime como filósofo” e propõe que esse mundo ideativo é como um espelho, um reflexo do real na mente, os dois modelos se complementam numa relação de "adequação" como verdade. Isso provém de um modelo matemático: $\mathrm{X}=\mathrm{Y}$. Tanto faz dizer: $\mathrm{Y}=\mathrm{X}$, para distinguir materialismo de idealismo. Quando Descartes faz sua "revolução moderna", ele se mantém no mesmo parâmetro de ideias claras e distintas, de modelo geométrico e matemático. Aí, um triângulo é uma figura geométrica com 3 ângulos, que não pode ter 4,5 ou 6 , embora os três outros estejam nela; um quadrado tem 4 lados, quando se esquecem de somar os de dentro com os de fora. O princípio da não-contradição é um meio de reprimir a liberdade de pensar. Ele está embutido na alegoria da caverna.
Um vetor central na "República” é que a sucessão de formas de governo ocorre pelas características de cada uma delas, pela dialética interna de suas contradições, e não pela ação externa de uma entidade como uma Divina Providência. A rigor, nesse sentido, dispensa-se a autoridade de um "mundo das ideias" que ditasse as regras do devir laico dos governos. Quando os cardeais escolhem um deles como papa, diz-se que eles foram inspirados por Deus, como se fossem meros executantes, coroinhas da vontade divina. Nem todos estão, no entanto, bem antenados. A Igreja Católica é uma monarquia eletiva, que foi durante séculos dominada pela aristocracia italiana. Agora tem um papa Chico disfarçado de argentino. Se ele fosse preto ou amarelo não faria diferença estrutural.

Se não há fator divino na evolução da história, o mundo das ideias também não precisaria existir como algo à parte. A "visão grega do mérito" não admitia mérito em quem não tivesse sangue nobre: o "filósofo" somente pode surgir entre os membros da "classe ociosa", assim como, na trilogia tebana de Sófocles, aquele que chega ao poder por mérito aparente, ser o mais esperto, Édipo, é filho do rei anterior. Quem diz que a esfinge se matou? Édipo. A esfinge do poder não se suicida só porque alguém enunciou ou denunciou sua natureza. Ela tem cara de pau e adeptos que votam nela. Ela sai do encontro disfarçada de Édipo, que nem sabe quem ele é.

A tese implícita de Sócrates é que alguém nasce pronto para governar, mas precisa ter uma formação escolar especial. Somente há de se desenvolver o país que tiver escolas de elite. Como escolher, no entanto, os mais aptos? Platão deixa isso por conta do milagre de 
alguém se libertar das cadeias que o prendem. Dribla assim o problema político.

Na parte final da obra, Sócrates diz que Glauco poderia criar também um "mundo das ideias", bastaria ir pelo campo com um enorme espelho, veria nele refletidas as nuvens, as árvores, até a si mesmo. As “ideias” são derivadas da realidade, a mente é como um espelho que reúne e sintetiza a imagem das coisas. Platão não é platônico. Se ele tem o mérito de ter desconstruído a proposição de um mundo de protótipos anterior a todas as coisas, no qual o cristianismo acreditou, não foi capaz de perceber que a inversão do mesmo não alterava o paradigma mimético básico, a verdade como adequação, como correspondência de $\mathrm{X}=\mathrm{Y}$. Parou de pensar onde devia começar.

\section{DO SENTIDO ESPIRITUAL}

Entre a linha do argumento dito filosófico e a linha do que é narrado na Politeia (que não é "republicana", como traduz), há contradições que precisam ser lidas. Talvez o autor não as tenha percebido, talvez as tenha intencionado. Tanto faz, ele está morto. Resta o que se tem do texto. A leitura sinedóquica tenta decifrar o todo pela parte, como se $o$ horizonte dela pudesse ser mais amplo por ter a liberdade da ficção, que acaba sugerindo mais do que o autor gostaria de dizer. 0 todo aqui não é apenas um livro, mas a estrutura da tradição metafísica.

Na parte final do livro VI, trava-se o seguinte diálogo:

“- E do múltiplo dizemos que é visto, mas não concebido, ao passo que as ideias são concebidas e não vistas?
- Exatamente.

- Pois bem: com que parte da nossa natureza percebemos as coisas visíveis?

- Com a vista-respondeu ele.

- E com o ouvido percebemos o que se ouve, $e$ por meio dos demais sentidos tudo o que é perceptível?

- Sem dúvida.

- Nunca notaste quão generoso foi o artífice dos sentidos para com a faculdade de ver e de ser visto do que para com as outras?

- Não, nunca.

- Reflete, então: existe alguma coisa de espécie diferente que seja necessária ao ouvido para ouvir ou à voz para ser ouvida - algum terceiro elemento sem o qual não possa haver audição?

- Nenhum - respondeu.

- Nenhum, com efeito - disse eu - e creio que o mesmo sucede com todas ou quase todas as outras faculdades. Ou podes citar-me alguma que necessite de tal adição?

- Não, por certo.

- Exceto a faculdade de ver e de ser visto. Não percebeste que essa, sim, necessita?

- Como?

- Porque ainda que haja vista nos olhos e o dono destes deseje ver, e ainda que a cor esteja presente nas coisas, se não se acrescentar um terceiro elemento especialmente adaptado a esse fim, nem a vista perceberá coisa alguma nem as cores serão visíveis? 
- A que elemento te referes?

- Aquele que chamas luz, respondi.

- Tens razão."1

Como não se pode conceber o múltiplo? Por que ele só pode ser "visto"? Quando Kant propôs o que ele chamou de "esquematismo", na Crítica da razão pura, estava pensando em imagens que são concepções complexas, sínteses figurativas de multiplicidades, de maneira que se poderia visualizar a ideia na configuração esquemática. A alegoria procura ser uma representação concreta, visível, de uma ideia abstrata. Quem compõe uma sinfonia tem uma imagem acústica complexa que pouco tem de visual. Seria possível, portanto, refutar a primeira frase citada. Além disso, há coisas visíveis que podem ser percebidas por outros sentidos que não a vista, como o tato, o olfato, o som e até o gosto.

A seguir se apresenta aí uma distinção entre visão e audição, sendo que na visão não bastaria ter um olho para ver e uma coisa para ser olhada: é preciso haver luz para que se possa ver. A luz é “ágathon”, condição de possibilidade, que foi traduzida, segundo Heidegger, na Idade Média por "Sumo Bem", ou seja, Deus como condição de possibilidade de todo o conhecimento: o parâmetro do conhecimento teria de ser o saber divino. Desse modo são formuladas ainda hoje as leis científicas, como universais e necessárias, com as características divinas da eternidade, da onipresença, da onipotência.

1 Platão, Diálogos III - A república, Porto Alegre, Editora Globo, 1964, tradução de Leonel Vallandro, p. 196-197.
Se "Deus é luz", estratégico era filtrar sua iridescência para que aparecesse aos homens como visão da transcendência: assim se ergueram em Chartres paredes mais altas na catedral, para que lá em cima a rosácea desse uma visão do divino, trazendo o deus cristão à terra. Do mesmo modo, a catedral da Sagrada Família em Barcelona cria um grande berço de luzes coloridas pelos vitrais para induzir à contemplação do mistério, enquanto a Beinecke Library, em New Haven deixa passar a luz em camadas finais de mármore colorido e gera uma visão do encanto dos grandes livros raros. A pura descrição técnica dos recursos utilizados para fazer isso é míope, incapaz de pensar o sentido deles.

Platão afirma que, ao contrário do que ocorre na visualização, na audição não é necessário nenhum terceiro elemento, além do ouvido e algo a ser ouvido. Ele está errado. Se não houver ar, água, metal ou algum outro meio para transmitir o som até o ouvido, não haverá audição. No vácuo perfeito não há audição, embora haja um ouvido e algo a ser ouvido. Por que ele erra? Por que um erro tão evidente não foi apontado?

Esse "terceiro elemento" é mais que uma coisa só. Também não basta haver luz para ver. Se alguém sofre de cegueira psíquica, não vai enxergar, ao menos conscientemente, mesmo que seus órgãos funcionem perfeitamente. Também não basta ter um olho bom e algo iluminado a ser visto para que haja visão: é preciso que os nervos transmissores funcionem e que os neurônios façam as devidas sinapses. Dentro da proposição de Platão, o cego não tem aquilo que mais caracteriza o homem. Como havia cegos na Antiguidade também, por que ele não levanta essa questão? Ele apenas expulsa os cegos da condição humana. 
Em suma, não se pode reduzir tudo a apenas um terceiro elemento, um "ágathon" para que haja visão. Não seria preciso, portanto, haver apenas um "Sumo Bem". Isso vai também se tornar relevante, no entanto, se considerarmos que, na busca da Verdade que se anuncia no livro VII, é preciso saber se ela é um meio para algo mais elevado que ela própria, como a Justiça, o Bem Comum, a Salvação Eterna, a sociedade perfeita, um povo eleito, uma classe salvadora. Toda vez que se submete a verdade aos interesses de uma instância considerada mais alta, ela acaba sendo sacrificada.

O que é o Sumo Bem na escravidão? Para o senhor, ter escravos dóceis e produtivos; para o escravo, ter um bom senhor. Qual é o Sumo Mal? Para o escravo, ser escravizado; para o senhor, ter escravos vingativos. Platão trata disso? Sim, nas Leis, ele sugere um bom meio termo para o senhor poder controlar os escravos, não sendo muito íntimo nem dependente, mas também não sendo agressivo arbitrariamente para não provocar vinganças. Aristóteles, no seu testamento, deu a liberdade a alguns escravos bons e presenteou outros a amigos e familiares quando morresse. Ele sabia, portanto, que não era bom ser escravo, mas confundia virtude com ter noção de como as coisas são.

Se para o leão é bom matar e comer a corça, para ela isso é bastante ruim, já dizia Nietzsche. O altruísmo feito para si mesmo é considerado egoísmo. O mesmo ato pode ser bom ou mau conforme a perspectiva com que seja visto. No Sumo Bem deve estar, portanto, o mal supremo também. Isso significa que o "princípio da não contradição" é um exorcismo, para que não se veja que o contrário pode estar contido no sujeito: quer-se que não apareça a possibilidade de se ver as coisas pelo avesso. Em vez de ser um princípio de correção, é um gesto de repressão do outro, da voz alternativa, do olhar pelo avesso.

Os gregos, parece, não tinham boa noção do vácuo, mas poderiam ter tido. Se Aristóteles, no Livro IV da Física, insiste tanto na noção de que, ao colocar um líquido dentro de um cântaro, ele não é colocado em um recipiente vazio e sim expulsa o ar que está aí dentro, ocupando o mesmo volume, ele tinha aí contada a noção de ausência de ar, de vácuo. Seria dialética primária. Por que Sócrates cai no erro de negar a existência de um terceiro elemento na transmissão do som? Por que ele se engana? Por que Platão não dá indícios de que há um erro aí? Por que Glauco é tão burro?

Sócrates insiste que somente a visão teria esse terceiro elemento. Quando sentimos um perfume, se não houver ar que transmita o odor ao nariz não vai haver percepção; quando degustamos um sabor, é preciso que haja mais que língua e papilas, ou seja, saliva; quando sentimos algo na pele, é preciso que haja a transmissão de um toque, algo mais que uma coisa a ser percebida e o tato para perceber: um toque que não seja forte nem fraco demais, sendo que somos mais sensíveis em certas partes da pele do que em outras.

Sócrates queria privilegiar a visão para privilegiar o Sol como divindade da qual tudo dependeria, centro do universo. Esse modelo persiste. Hoje, ele poderia insistir que a vista é o órgão que mais provoca reações neuronais quando o sujeito é submetido a estímulos. "Você viu” significa percebeu, verificou, constatou. 
Teria sido tão fácil dizer que cada sentido precisa de um terceiro elemento, uma condição de possibilidade. Por que insiste em negar? Ele queria ver no sol a forma mais parecida com 0 olho, o ícone do próprio saber. Ele diz isso. A fogueira dentro da caverna como um sol em miniatura, de uso doméstico.

Sócrates nega as evidências para impor sua interpretação. Ele força a barra, ele mente. Ele é o sofista que ele acusa outros de serem. Por quê? Para quê?

\section{O INICIADO}

\section{No início do livro VII, tem-se o mais famoso texto da filosofia, uma fábula:}

"- E agora-disse eu - compara com a seguinte situação o estado de nossa alma com respeito à educação ou à falta desta. Imagina uma caverna subterrânea provida de uma vasta entrada aberta para a luz e que se estende ao largo de toda a caverna, e uns homens que lá dentro se acham desde meninos, amarrados pelas pernas e pelo pescoço de tal maneira que tenham de permanecer imóveis e olhar tão só para a frente, pois as ligaduras não lhes permitem voltar a cabeça; atrás deles e num plano superior, arde um fogo a certa distância, $e$ entre o fogo e os encadeados há uma caminho elevado, ao longo do qual faze de conta que tenha sido construído um pequeno muro semelhante a esses tabiques que os titiriteiros colocam entre si e o público para exibir por cima deles as duas maravilhas.

- Vejo daqui a cena-disse Glauco.

- E não vês também homens a passar ao longo desse pequeno muro, carregando toda espécie de objetos, cuja altura ultrapassa a da parede, e estátuas e figuras de animais feitas de pedra, de madeira e outros materiais variados? Alguns desses carregadores conversam entre si, outros marcham em silêncio.

- Que estranha situação descreves, e que estranhos prisioneiros!

- Como nós outros - disse eu. - Em primeiro lugar, crês que os que estão assim tenham visto outra coisa de si mesmos ou de seus companheiros senão as sombras projetadas pelo fogo sobre a parede fronteira da caverna?

- Como seria possível, se durante toda a sua vida foram obrigados a manter imóveis as cabeças?

- E dos objetos transportados, não veriam igualmente apenas as sombras?

- Sim.

- E se pudessem falar uns com os outros, não julgariam estar se referindo ao que se passava diante deles?

- Forçosamente.

- Supõe ainda que a prisão tivesse um eco vindo da parte da frente. Cada vez que falasse um dos passantes, não creriam eles que quem falava era a sombra que viam passar?

- É indubitável.

- Para eles, pois - disse eu - a verdade, literalmente, nada mais seria do que as sombras dos objetos fabricados.

- Também é forçoso.

- Torna a olhar agora e examina o que naturalmente sucederia se os prisioneiros fossem libertados de suas cadeias e curados 
da sua ignorância. A princípio, quando se desate um deles e se obrigue a levantar-se de repente, a virar o pescoço e a caminhar em direção à luz, sentirá dores intensas e, com a vista ofuscada, não será capaz de perceber aqueles objetos cujas sombras via anteriormente; $e$ se alguém lhe dissesse que antes não via mais do que sombras inanes e é agora que, achando-se mais próximo da realidade e com os olhos voltados para objetos mais reais, goza de uma visão mais verdadeira, que supões que responderia? Imagina ainda que o seu instrutor lhe fosse mostrando os objetos à medida que passassem e obrigando-o a nomeá-los: não seria tomado de perplexidade, e as sombras que antes contemplava não lhe pareceriam mais verdadeiras do que os objetos que agora lhe mostram?

- Muito mais - disse ele.

- E se o obrigassem a fixar a vista na própria luz, não lhe doeriam os olhos e não se escaparia, voltando-se para os objetos que pode contemplar, e considerando-os mais claros, na realidade, do que aqueles que the são mostrados?

- Assim é-respondeu.

- E se o levassem dali à força, obrigando-o a galgar a áspera e escarpada subida, e não o largassem antes de tê-lo arrastado à presença do próprio Sol, não crês que sofreria e se irritaria, e uma vez chegado até a luz teria os olhos tão ofuscados por ela que não conseguiria enxergar uma só das coisas que agora chamamos realidades?
- Não conseguiria - disse ele - pelo menos no primeiro momento.

- Precisaria acostumar-se, creio eu, para poder chegar a ver as coisas lá de cima. O que veria mais facilmente seriam, antes de tudo, as sombras; depois, as imagens de homens e outros objetos. Alçaria então os olhos para a Lua e as estrelas, e veria o céu noturno muito melhor do que o Sol ou a sua luz durante o dia.

- Como não?

- E por fim, creio eu, estaria em condições de ver o Sol-não suas imagens refletidas na água ou em qualquer outro lugar que não seja o seu, mas o próprio Sol em seu próprio domínio e tal qual é em si mesmo.

- Necessariamente - disse ele.

- Mais tarde, passaria a tirar conclusões a respeito do Sol, compreendendo que ele produz as estações e os anos, governa $o$ mundo das coisas visíveis e é, de certo modo, o autor de tudo aquilo que o nosso prisioneiro libertado e seus companheiros viam no interior da.

- É evidente - concordou Glauco - que veria primeiro o Sol e depois raciocinaria sobre ele.

- E quando se lembrasse de sua anterior habitação, da ciência da caverna e de seus amigos companheiros de cárcere, não crês que se consideraria feliz por haver mudado $e$ sentiria piedade deles?

- Com efeito."2 
A ação se passa em quatro momentos distintos: 1) o status quo de funcionamento da caverna, com sua encenação de sombras; 2) um prisioneiro se liberta; 3 ) ele sai da caverna; 4) ele volta para a caverna. A “ação" que conta é a que é contada, a do protagonista: não importa o quanto façam os serviçais físicos e espirituais. Da perspectiva cristã, ele só pode sair da caverna morrendo. Há alguns iluminados que acham que com a contemplatio mystica Dei já chegaram lá. Há gênios e artistas e malucos que acham que dão esse giro também.

Se a caverna é o mundo em que estamos, não se pode sair dela em vida. Quem vive sabe, porém, que a caverna é exceção, não regra. Todos sabem que há um mundo fora da caverna. Por isso, é muito estranho que acabe voltando quem dela saiu. Há um sofisma na própria imagem, ela dita suas consequências.

Um missionário cristão ou um militante partidário é alguém que acredita ter encontrado uma saída: ele volta para salvar os demais, convertendo-os à "boa nova". Querer que o mundo externo seja visto como imaginário se contrapõe ao bom senso. $\mathrm{O}$ argumento de Platão quer induzir, no entanto, a contemplar a fogueira de verdade, o Sol, e não sua pequena imitação como fogueira.

O "mundo da caverna" não consegue se sustentar, porém, sem o mundo externo. De onde se vai tirar a lenha para alimentar a fogueira, já que não se tem uma fonte de petróleo? De onde os escravos vão buscar os alimentos para cuidar dos preguiçosos que não fazem nada? Para onde os enfezados vão levar seus excrementos? E os escravos artistas, não é lá de fora que eles vão buscar o material (madeira por exemplo) e a inspiração para o teatro que encenam? Ou seja, antes de o "filósofo oriundo da classe ociosa" conseguir sair, os escravos já saíram e já voltaram, mas isso não conta, pois só o saber da classe alta é que conta. Kant era filho de um carpinteiro. Cristo também.

Essa parábola, que fundamenta a gnosiologia ocidental, ignora seus fundamentos, repousa em deformações. A caverna é uma casa, uma moradia coletiva, uma síntese social, um modo de compreender o mundo em miniatura. Ela é, nesse sentido, uma estrutura psíquica, um modo de entender o mundo, a estrutura social. Glauco é quase débil mental, não apresenta as objeções mínimas que deveria. Ele não cresce com o questionamento. Deixa passar o evidente, ajuda a cegar, não constitui voz alternativa.

Na "parábola do Bom Samaritano” não se questiona a lógica proposta de dividir todos os recursos, escassos, conforme as necessidades, infindáveis. Quando se lê isso no púlpito, não se está propondo uma discussão. Há uma sacralização da palavra, como professores sacralizam textos filosóficos, sociológicos ou literários. Há uma canonização da leitura canonizante do canonizado. Assim não se vai além do texto e, por isso, não se chega até ele. Quem respeita demais a santa não dorme com ela.

A “República” tem a forma de um diálogo, é um diálogo aparente, mas não é dialógica, não tem a dialética do argumento e do contraargumento, de vozes que se contrapõem e entrelaçam É um catecismo doutrinário. A única polifonia que apresenta é quando Sócrates apresenta uma objeção a si mesmo, em 
relação ao modo de existência do mundo das ideias. Mesmo aí, onde deveria surgir a questão da identidade homoiética de protótipo ideal e reflexo mental em relação às coisas, não se desenvolve $o$ argumento.

Essa parábola, uma alegoria em forma de narrativa, é apresentada como mito da caverna embora não seja (o mito tem autoria anônima, coletiva): tem algo incompatível entre estrutura significativa e sentido atribuído. Há um gap aí. A leitura alegórica serve para reforçar o caráter autoritário do que pretende ser mítico e não ficcional. Mistifica-se. O milagre da libertação, o afloramento do gênio, serve para efetivar a escolha daquele que tem aptidão para questionar as coisas, o filósofo, que há de ser o governante.

Essa “eleição” é misteriosa. Depende do acaso. Não há critério. Serve para omitir a política: essa é a sua política. A aparência de se livrar das cadeias tem sentido figurado, significa quem é capaz de ver as coisas de uma perspectiva inusitada, quem detecta as sombras como sombras e não como aparição de coisas. Isso é mais problemático do que se soltar de correntes.

Os que estão submersos nas sombras e aqueles que sustentam com seu trabalho essa estrutura não estariam dispostos a aceitar o golpe de Estado do "filósofo". Como iria ele viabilizar sozinho o governo? Ele não saberia fazer coalizões, concessões. Colocar filósofos a governar o Estado seria um desastre. Eles tendem a não governar do melhor modo o próprio departamento. Na época de Kant, Fichte, Solger e Hegel, a universidade colocou filósofos como reitores de suas universidades, o que é um modo eficiente de matar o pensador com tarefas burocráticas.
O problema da aristocracia é encontrar o mais capaz para governar, não substituí-la por outra forma de governo. Os escravos aceitam ser escravos, sofrem menos assim. Eles sim é que gostariam de sonhar com outro mundo, melhor do que esse em que estão. Os "artistas” aí são escravos como os outros que cuidam do corpo senhorial: eles tratam de entreter as mentes, sem acrescentar nada que induza a ver um mundo mais verdadeiro.

O olhar dos ociosos, manietado e manipulado, é o olhar do técnico e do cotidiano. Obedece a paradigmas, pensa conforme o sistema quer que se pense. Pensam que pensam, para não pensar a valer. Toda vez que suas elucubrações poderiam destoar - há luz alternativa que vem da entrada da caverna, há movimento de corpos, há fímbrias de luz em torno das sombras -, cessam o pensar, não pensam adiante, não tiram as consequências. Neles se tem o eterno retorno do mesmo.

\section{O DONO DA VERDADE}

Aparenta-se procurar o filósofo, para buscar o governante. Ele não pode provir dos que trabalham: essa é a ideologia aristocrática de Platão, como era de Sófocles. Um problema sério da nobreza é que nem sempre o predestinado ao poder tem vocação e habilidade para governar. 0 aparente filósofo, pois filósofo das aparências, aparece marcado pela ânsia de poder, o que tende a fazer com que aceite todos os jogos de simulação inerentes à política. Platão, o escritor, faz uma caricatura do filósofo como alguém que ama mais o poder do que o saber. Assim como o sofista é criticado pelo amor ao dinheiro, esse "filósofo" pode ser 
visto como aquele que ama o poder. A ânsia de ver o fundamento de todas as coisas, de conferir o caráter de conhecimento absoluto, esconde a ânsia desmesurada de ter o controle de tudo.

Tem-se aí uma síntese imagética, um "esquema", da sociedade da época sob a forma de duas classes presas dentro da caverna: a classe ociosa, dos aristocratas, e a classe dos que servem a ela, os escravos. Estes se subdividem em dois tipos: aqueles que cuidam do sustento material e aqueles que providenciam diversão. Radical nessa crítica é que não há razão para os ociosos serem servidos: são parasitas manietados, amarrados, iludidos por aparências. Eles tomam sombras projetas na parede como se fossem a própria realidade, e não querem sair disso. Como poderiam impor sua vontade, obrigar outros a servi-los continuamente?

Para resolver o impasse de selecionar um escolhido sem fazer política nem eleição, um dos manietados se solta das amarras e vai em direção à saída, onde será iniciado no segredo de que o Sol tudo determina e é o centro do universo. Ele acha que o Sol determina tudo sozinho, inclusive as estações do ano, como se o movimento da Terra não tivesse importância. $\mathrm{O}$ que parece mais verdadeiro também é fundado na aparência. Ou seja, o que Sócrates propõe é a doutrina egípcia de Athon (monoteísmo que foi imposto ao povo judeu e endossado pelo cristianismo). No primeiro momento, o liberto não consegue olhar as coisas muito iluminadas e precisa se voltar para suas sombras e seus reflexos na água; no segundo, ele volta à caverna para libertar seus colegas do ócio, mas estes não querem sair de sua acomodação. Ele não cogita libertar os que trabalham. Aqueles que mais precisam de liberdade não são considerados. Não são gente.

Outra “iluminação” é que esse “iniciado” não apenas acha que é o dono da verdade e, por isso, se considera no direito de assumir o poder, mas consegue transformar todo o sistema sem uma ação política partidária. São passes de mágica para dissolver impasses. Supõe que está gerando um mundo mais justo, como se pessoas mais escoladas já estivessem por isso mais dispostas a trabalhar pelo bem comum, não em amealhar benesses. Não se admite aí crime do colarinho branco. Há leniência.

O modo estratégico de defender aí a nova proposta é deixar o "antagonista" apenas a dizer amém, feito um coroinha, não admitir críticas nem ver a necessidade de reformular o sistema, não estabelecer controles para preservar o interesse público, para impedir a corrupção e a manipulação. $\mathrm{O}$ antagonista é um pseudoantagonista. Seu "diálogo" é como o do catecismo, em que a pergunta não serve para questionar nada, mas está aí apenas para propiciar a doutrinação, cuja resposta é anterior à pergunta.

Quem iria propor a revisão do sistema instituído seria o gênio: ele teria de ser, então, expulso. Ou seja, a dialética cessa aí quando convém se tornar conservador, preservar uma forma de governo. Não se admite mais a antítese nem o contraditório. Que o sujeito não queira admitir isso não significa, no entanto, que a negatividade, a repressão, a propaganda falsificadora e a contradição não continuem a existir em atos e fatos. 
Aquele que se apresenta aí como “filósofo” acha que é dono da verdade. $\mathrm{O}$ senso comum e a religião grega acreditavam que o Sol gira em torno da Terra levado por uma carruagem conduzida por Apolo (um deus antropomórfico que ainda persiste na versão loira de Cristo). 0 pretenso filósofo está certo ao dizer que a Terra gira em torno do Sol, mas erra ao supor que este é o centro do universo e determina tudo sozinho.

Ele pretexta ser o primeiro a sair da caverna e contemplar a realidade externa, mas antes dele já tiveram de ir lá os manipuladores de bonecos, ao buscarem seus modelos, e os escravos, ao procurarem alimentos, roupas e madeira para a fogueira. O que a classe dominada faz e pensa é considerado como não tendo valor, é como se não existisse. O sabichão é arrogante, prepotente e totalitário. Se ele já é assim quando está sozinho e ainda não tem o poder, pode-se imaginar o que ele faria quando tivesse o governo, a máquina do Estado e um partido organizado.

Se aquilo que esse pseudofilósofo, o candidato ao poder, supõe e afirma ser a verdade é fundamentalmente corrompido e não é verdadeiro, o sistema daí derivado não vai poder ser mais justo nem mais voltado ao bem comum. Esse bem comum acaba sendo, na prática, o bem privado de uma classe, em detrimento do bem comum de outras comunidades exploradas. Assim como não é questionada a exploração interna dos escravos, também não seria questionada a espoliação de outras comunidades. Pelo contrário, considerando-se mais justa, ela iria se sentir no direito de explorar as outras.

O termo "filósofo" revela-se inadequado. Ele não ama o saber, ele ama o poder. Mente para alcançar o poder. Ignora a atividade dos escravos e dos artistas, ignora que já saíram da caverna antes dele. Ele é um teólogo, um missionário à toa de Athon. Logo essa casta poderia considerar parte do bem comum eliminar os que ela consideraria inimigos do Estado. Portanto, a obra Politeia não é a proposição de uma "República”, conforme vem sendo traduzido como algo progressista, contrário à monarquia e à aristocracia de sangue, mas é uma proposta reacionária, a teocracia de uma casta sacerdotal escravista, em que se extingue o avanço de separar poder civil, militar e religioso.

\section{DILEMAS DA MERITOCRACIA}

A posição do artista, nesse sistema da caverna, é precária. Ele não tem o que dizer. O labor dele só quer ser diversão agradável, não leva à elevação da consciência, não tem compromisso com a verdade ou, se tem alguma, isso não é reconhecido pelo público. Tudo o que ele faz não muda nada. Ele é um escravo dos ociosos, existe para passatempo. Ele é inútil como os inúteis para os quais se esforça. Se serve para manter as relações sociais, sequer serve para restaurar as forças de produção. Ele não se dedica a quem trabalha. Vale menos que artista de telenovela. Função da arte é divertir a oligarquia em suas festas, como o rapsodo que aparece em Homero.

O único artista maior aí é o autor de toda a proposição, Platão, que via no tirano a pior espécie de homem. Como delega o monopólio do dizer a Sócrates, que fala praticamente sozinho, gera um tirano da fala. $\mathrm{O}$ "artista” é como o "antagonista” que não chega a ser antagônico: 
fica apenas concordando. Nem aplaudido ele é, pois não fez mais que a obrigação. Que Platão era capaz de articular contraposições mais contundentes, isso ele demonstrou no Simpósio.

Na República se sugere que há três tipos de pessoas: homens de ouro, homens de prata e homens de ferro. As mulheres não contam. Democraticamente diz-se que não é pelo fato de alguém ser um homem de ouro que o seu filho há de ser de ouro. Na teoria, um filho de ouro pode surgir de um pai de ferro. Estranho é que ele não aplique esse princípio na organização da vida dentro da caverna e exclua do acesso à filosofia todos os que fazem trabalhos manuais ou artísticos. Os escravos, que precisam ter uma resistência de ferro para fazer tudo, não são sequer homens de ferro. O ferro é mais útil do que ouro e prata, mas menos valioso nessa lógica do adorno.

Não se rompe fácil com a aristocracia de sangue se ela está na base do sistema teológico politeísta. Os homens de ouro tenderiam a considerar como parte de sua obrigação promover os estudos e a profissionalização dos filhos em termos dourados, tratando de gastar mais na formação deles. Por outro lado, se criaria o máximo de dificuldades a "espertos oportunistas" oriundos das classes baixas. A maneira de definir a diferença entre os metais, em sua passagem para o plano simbólico, já não seria mais tão clara. Demandaria interpretações. A exegese tenderia a ser feita de acordo com as conveniências de quem estivesse no poder. Se desde o começo a luta pelo poder demanda a mentira sistemática, na manutenção do poder isso tenderia a piorar. Quanto mais acerba a luta de classes, maior o sacrifício da verdade.
Não se discutir o caráter histórico e classista do mérito, os paradigmas de sua avaliação, supondo que possam ser sempre os mesmos, isso é sintomático. Acaba sendo de ouro quem consegue mais poder, por piores que tenham sido os métodos adotados. Pode-se objetar que, na Igreja Católica, o filho de um camponês polonês ou da classe média alemã chegou a ser papa. Demorou vinte séculos para chegar a isso. Nunca houve até hoje um papa preto, chinês. Não faria diferença: ele seria parte do esquema, traindo sua origem. Roma chegou a ter um César de origem espanhola, sem que a província ibérica fosse emancipada. Um sujeito só vai chegar ao poder e se manter nele caso se sujeite aos esquemas e propósitos da instituição.

A meritocracia é tão problemática quanto outras formas de governo, pois pressupõe que quem chega ao poder tenha todo mérito por isso, sendo ele divinizado e impedindo-se que se relatem fatos denegridores. Sufoca-se a discussão pública do que seja mérito. O Santo tem todo espaço na mídia. Dá-se a ele uma autoridade moral que a instituição não merece. A escolha dele feita por um colegiado de eminências rubras é alardeada como se decorresse de uma inspiração divina. A autoridade dele é vista como decorrente de ele ser o representante de Deus ou do Ideal na Terra. Nos Estados governados pelo partido comunista pretendeu-se a meritocracia e acabou-se tendo uma dominação russa e uma gerontocracia incapaz de fazer as mudanças que gerassem melhores condições de vida. A divinização de genocidas se baseia em o líder ser visto como representante do ideal, caminho para toda a humanidade. 
A meritocracia proposta por Platão apenas aparenta ter caráter revolucionário. $\mathrm{O}$ que ela propõe é uma ditadura escravista. As famílias aristocráticas gregas se diziam descendentes de alguma divindade, o que supunham lhes dava 0 direito a terras, gado e gente. Mesmo quem ousava pouco já ousava demais: não por acaso Sócrates, Platão, Eurípides e outros foram perseguidos. Viver em Atenas seria intolerável para nós.

Platão percebeu o perigo totalitário da utopia da "República": para manter real a sua ficção, teria de eliminar todo gênio criativo que fosse capaz de imaginar uma alternativa a ela. Não apenas teria de ser banido um escritor admirável como Homero, mas também o próprio autor ou seu equivalente. Platão expulsa Platão. Assim ele sepulta o próprio projeto, que vale como teoria, não como prática, embora tenha virado religião no ocidente.

O passo adiante em Platão, que o leva além do platonismo, é que ele questiona o mundo que ele propôs: ele é uma ficção virtual, como as imagens que aparecem num espelho. Não se questiona, porém, o regime político e sua base social. É preciso distinguir, portanto, o que Sócrates diz, como personagem, daquilo que Sócrates pensa e não diz; aquilo que é dito em conceitos e o que é mostrado em imagens; aquilo que Platão escreve como dramaturgo de ideias e o que ele sugere.

Além desse sistema de caixinhas em caixas, ou de bonecas dentro de bonecas, há o que se pode pensar para além do conteúdo manifesto do escrito. Na matrioska se espera que a próxima boneca seja igual à anterior. Cada ampliação modifica o sentido de cada parte; cada parte modificada altera a parte maior seguinte. Não há um todo, pois ele é sempre parte. Como não há todo, não há espaço para totalitarismos.

Ao não se entrar no jogo ideológico aí instituído, cabe perguntar onde a imagética proposta por Platão deixa de ser filosófica para corresponder à perspectiva aristocrática, ainda que também seja profundamente crítica em relação à nobreza dos nobres. Por que a necessidade de só a visão ter um terceiro elemento, a luz, como condição de possibilidade? Para priorizar a contemplação do Sol, como divindade, valor supremo. Só quem sai da caverna pode chegar ao poder: não vale o valor agregado dos demais sentidos, a mobilidade dentro da caverna como mudança. Se a caverna é aceita como modelo, é preciso aceitar suas consequências e sequelas. Uns são mais iguais que os outros.

\section{A leitura de HeIdegGer}

Heidegger fez a leitura desse mito da caverna em diversas partes de sua obra, como as aulas de 1933-34, fez um livro específico sobre o mito da caverna, o tema reaparece quando ele trata da concepção de verdade, nos livros sobre Nietzsche, etc. Ele queria fazer uma leitura exata e profunda da concepção de "verdade" aí fundada e do que deveria ser o filósofo como protótipo do homem. Ele foi omisso, porém, no político e ideológico. Heidegger fez em 1933-34 uma crítica explícita ao marxismo, mas, em plena vigência do nazismo, ele defendeu a liberdade como fundamento da verdade. Depois da guerra, ele foi impedido de lecionar por cinco anos, durante a era da "libertação democrática”. Se alguém, no período das aulas de 1933-34, tivesse feito 
observações como as seguintes, ele poderia ter se tornado suspeito. A ditadura militar no Brasil eliminou professores heideggerianos da universidade, enquanto a ditadura nazista tolerou Heidegger, embora ele fosse vigiado pela Gestapo.

O que Heidegger parece não perceber no mito da caverna é: 1) a espoliação do trabalho a que são submetidos escravos e artistas; 2) os artistas saíram antes do filósofo para fora da caverna, porque se não eles não teriam modelos visuais e sonoros para imitar nas projeções dentro da caverna; 3) os escravos também saíram antes, para prover madeira para o fogo e alimentos para os senhores ociosos; 4) Sócrates tinha origem não aristocrática, mas apregoa que o filósofo não pode se originar senão da aristocracia ociosa, embora artistas e escravos estivessem já a fazer o percurso para fora e dentro da caverna; 5) o que ele chama aí de filósofo não é um filósofo e sim um ideólogo oligarca, que quer um modo novo de assegurar o antigo poder; 6) o "filósofo" não tenta libertar escravos e servos, que tinham menos a perder e mais a ganhar, pois se volta apenas para membros da classe ociosa; 7) o "filósofo" não tem aí um compromisso vital com a verdade, mas ele ajuda a ocultá-la, para conseguir o poder para si; 8) a "verdade" central do filósofo não é verdadeira, pois o Sol não é o centro do universo nem determina sozinho o calor e a luminosidade na Terra; 9) o aí apregoado culto ao monoteísmo, baseado no culto egípcio ao deus Rah-Athon, não é reconhecido como crença religiosa, mas tanto melhor serve para fundar o platonismo cristão; 10) comprometido com o poder da aristocracia de sangue, o pseudofilósofo busca apenas um modo de aperfeiçoar seu modelo, sem ver os impasses de uma meritocracia que se recusa a questionar o que entende por mérito; 11) apresenta-se como filósofo quem é guardião dos interesses de uma classe; 12) apresenta-se como verdade o que oculta verdades mais substanciais da situação; 13) a pretexto de só buscar a verdade, busca-se uma instância mais elevada, da qual ela se torne dependente; 14) sendo a verdade dependente de algo maior, ela abdica de si; 15) nesse sentido, há coerência entre o proposto e o praticado na parábola.

Nietzsche já havia, no entanto, colocado sob suspeita a figura do filósofo, por sua pretensão de ser dono da verdade e do poder. Heidegger leu Nietzsche intensamente, leu essa suspeita, acha que seria ruim para o governo se catedráticos de filosofia assumissem altos postos, mas não entendeu bem a política do texto. Sendo a central na filosofia a verdade, Marx não a examinou explicitamente e isso se mostra no modo confuso como usa o termo "ideologia”: 1) falsa consciência; 2) consciência histórica revolucionária do proletariado; 3) conjunto de áreas do saber que envolvem relações sociais. Aí, uma vez a ideologia é falsidade e outra vez pretende ser a verdade da história. Freud também não deixou bem claro como distinguir um raciocínio de uma racionalização. Interesses podem impedir o conhecimento como podem promovê-lo.

O impasse do filósofo afeta o que se entende por verdade. Se o “filósofo" é um ideólogo de classe, ele não se reconhece como tal; se ele se reconhece, isso não garante que seja verdadeiro o que diz. Ele poderia ser um ideólogo dos escravos ou dos serviçais e artistas, mas isso não significaria ter maior compromisso com a verdade. Ele defenderia apenas a anterioridade da saída destes da caverna, poderia até propor que senhores e 
servos invertessem suas posições, sem que isso alterasse a estrutura fundante. Nada mais conservador que tal "revolução".

Problema similar aparece na trilogia tebana de Sófocles. Aparentemente, já se tem nela a proposta revolucionária de uma monarquia do mérito, em vez de ser de sangue. Édipo assume o poder porque foi o único, diz-se, a conseguir decifrar o enigma da esfinge, figura que causava graves prejuízos sociais. Ninguém sabia, diz-se, que Édipo tivesse sangue real. Ele ascende ao poder por mérito. Só que, como no mito da caverna, o que melhor pensa somente pode surgir da aristocracia. Com isso, anula-se o avanço. Desloca-se a questão para a de conseguir determinar quem teria mais mérito entre os aristocratas. Nem sempre seria o filho mais velho. A alternativa seria transformar a classe do mérito em nova aristocracia.

Sendo apresentado só como filósofo quem também é ideólogo político e religioso, num texto que não propicia a abertura a um debate sobre isso, propõe-se como guardião da verdade quem é depositário da confiança de uma classe (mas como se não fosse, fazendo-se um teatro da libertação): se apresenta como ameaçado pela classe dominante enquanto está a serviço dela, sendo seu agente disfarçado. Ainda que Heidegger admita que a inverdade faça parte da verdade, que todo desencobrimento envolve encobrimentos, ele não decifra esse condicionamento para estudar a possibilidade de ir além dele. Como é que alguém tão inteligente não viu aspectos tão básicos? É como se não houvesse classes nem política para a filosofia. Elas também não são por si garantia de verdade ou mentira. Heidegger tem dificuldades no horizonte ideológico, ele é politicamente ingênuo. Filosofia não é, porém, teoria sociológica: é ir além dos limites ideológicos.

Que a figura do filósofo possa se originar de classes que não a aristocracia de sangue é fato histórico. Descartes e Pascal provinham da burguesia, não eram da aristocracia tradicional francesa. Kant era filho de um carpinteiro. Vários nomes do pensamento alemão só conseguiram se formar porque foram internos de escolas de elite do Estado ou da Igreja Luterana: Fichte, Hölderlin, Schelling, Hegel, Nietzsche. Poucos eram, como Schopenhauer, oriundos de famílias ricas, não tendo de trabalhar para sobreviver.

Dificuldades políticas estimularam talentos pobres a pensar, mas sem condições materiais não podiam produzir. A repressão quebra a espinha do pensador ao lhe tirar condições de produzir, mas não faz produzir quem as têm. A aristocracia, que pode fornecer as condições educacionais, ambientais e materiais para que seus jovens membros evoluam e se tornem filósofos, artistas ou cientistas, não produziu tantos membros de destaque. É como se condições a mais ou a menos sabotassem resultados. Heidegger provinha de uma família católica relativamente pobre e só conseguiu se desenvolver com auxílio da Igreja, da qual se tornou um apóstata.

Heidegger não saiu da Alemanha durante o período nazista não só por causa de simpatias que chegou a ter com aspectos do movimento, mas porque estava preso à língua alemã. A Áustria deixara de existir; a Suíça não tinha tradição de receber filósofos germânicos, Nietzsche foi professor de grego e latim lá, recusado pelo departamento de filosofia. 
Heidegger assumiu a reitoria da universidade de Freiburg, para impedir o expurgo e professores judeus, mas ousou se demitir quando voltaram a ocorrer. Ele ainda não tinha o renome que hoje tem, embora Sein und Zeit fosse uma obra logo reconhecida.

Heidegger supõe que somente o ser humano pensa e tem linguagem e senso para o ser. Isso parece teologia cristã disfarçada: somente ao homem seria dada uma alma por Deus. Assim se facilita o domínio do planeta, a utilização indiscriminada e cruel de todos os seres vivos, faz-se uma massagem no ego narcisista de quem pretende ser superior. É um erro central. Não se trata de bater boca à base de uma crença. Quem já conviveu com animais, sabe que eles se comunicam, têm noção do próprio morrer, conseguem derivar conclusões a partir de experiências singulares, são éticos ainda que sua ética varie conforme a espécie. Nietzsche viu isso com bastante clareza e estava, nesse sentido, mais avançado que Heidegger.

\section{DA ESSÊNCIA DA VERDADE}

No curso de inverno de 1933-1934, Da essência da verdade, Heidegger retomou o mito da caverna. Enfatizou, na quarta etapa do percurso no mito da caverna, o papel libertador do filósofo: "o homem não é enquanto está preso na caverna, se sente bem e conversa, mas o homem é como transição da caverna à luz e de volta à caverna. (...) 0 filósofo é tanto mais solitário quanto menos pode se retirar da caverna. 0 que ele vê é diferente do que avistam os

3 Heidegger, Martin. Sein und Wahrheit, HGA 36/37,

Frankfurt a.M., Klostermann Verlag, 2001, p. 182 - 183. provedores da caverna. Como no processo histórico a verdade e o desvelamento se modificam e elevam."3 Ele é solitário ao tentar ser solidário (com o grupo errado talvez) e dizer o que não seja apenas conversa corriqueira. $O$ homem é o animal que tenta ser divino e quer a transcendência que não lhe cabe. Ele se torna prisioneiro de suas crenças.

A noção de verdade aí é de algo que muda objetivamente, não sendo mera opinião. Ela não é absoluta, mas uma tensão entre luz e sombra. Há um duplo sentido da verdade, conforme ela se refira à fogueira ou ao Sol. Ao se falar em caverna, é inevitável que se fale de um mundo fora da caverna, além dela, um mundo do divino. Não se fala de seres humanos capazes de sobreviver apenas dentro da caverna, como peixes cegos, aranhas e crustáceos.

Propor a caverna como fábula implica admitir um mundo além. Há uma imposição do significante. Fica difícil, porém, admitir que a única alternativa do filósofo seja voltar para a caverna e se debater com seus coevos. Ele seria mais esperto se saísse para sempre, como emigram do seu país os que não estão contentes com ele. Outro jeito de sair seria ter um céu feito de livros e manuscritos, mas seria preciso que o sujeito fosse sustentado por escravos, mesmo que sob a forma de impostos. A noção de ameaça latente nos colegas pode levar 0 sujeito a produzir para a posteridade, deixando um baú ou uma pilha de manuscritos, como fizeram Pascal, Marx, Nietzsche, Heidegger, Fernando Pessoa. Muitos manuscritos acabam sendo queimados numa faxina póstuma. 
A necessidade de sair da caverna serve não para ver as coisas como elas são, mas para se certificar da existência do Sol, como representação do "ágathon", desde condição de possibilidade de conhecimento até Sumo Bem. Poderia ser a Justiça, ou o Bem Comum também. A verdade não é a última instância, ela se subordina a algo mais elevado. Quando isso acontece, passa-se a tomar por verdade, no entanto, o que esteja de acordo com o que se quer como "ágathon".

Para isso foi preciso dizer, no livro VI, que apenas a visão necessita de um terceiro elemento, a luz, para que funcione, embora todos os demais sentidos também tenham necessidade de um terceiro, um quarto e um quinto elemento. Sócrates engana, mente. Negase que os demais sentidos precisem de um terceiro elemento além do órgão e da coisa para que se privilegie a visão da divindade, o Sol. Se a única verdade está fora, não se percebem, dentro da caverna, alternativas que abram outro modo de "conceber" (não apenas "ver") as coisas.

Se ninguém pode sair inteiro da "caverna", como é que dentro dela se poderia ter maior noção da verdade? Ou a verdade é o valor supremo, doa a quem doer, ou ela é sacrificada ao mais elevado, ao "correto" conforme paradigmas "superiores”. Crimes são cometidos em nome da virtude e criminosos dormem sossegados na cadeia enquanto homens de bem se revolvem inquietos na cama, já dizia Nietzsche. Caso se admita o "terceiro elemento" para todos os sentidos, pode-se concluir a necessidade de ter um princípio superior de referência, ao qual se subordine toda descoberta da verdade. Ela então pouco importa, já que há algo superior. Não estavam tão errados os medievos católicos ao entender a condição de possibilidade como Sumo Bem, Deus, e Deus como luz. Quem tudo cria, propicia todo conhecimento. Se há uma instituição que o representa, tudo se faz em nome desse valor supremo. A verdade é “adaptada” a ele. Ela é extinta em nome de algo maior.

O que distinguiria o "filósofo" não é que ele não fique vendo sombras, mas que perceba as sombras como sombras, enquanto os ociosos comuns as tomam por coisas reais. Será que, no entanto, os manipuladores de bonecos não sabem que estão projetando sombras? Devem saber o que estão fazendo. O domínio da técnica envolve saber a verdade. Que o trabalhador domine a técnica é menosprezado. O filósofo profissional não é o primeiro nem o último dos sabichões. Quando ele idolatra um filósofo do passado, do qual se torna gigolô, ele vê uma sombra, não o pulsar vivo que levou ao filosofar. Toda filosofia é engajada, mas ela não pode se perder na circunstância imediata.

Da verdade fazem parte tanto a parte iluminada quanto as sombras. Ambas são constitutivas do ser. Não é verdadeiro dizer apenas sombras; também não é se deslumbrar apenas com luzes. Quando um Heidegger lê o "mito da caverna", ele o aceita como tal, como se mito fosse, não um arranjo feito por um autor. Será que o "mito" reproduz em síntese uma imagem correta do que se passa na sociedade? Sua idealização nos “estudos clássicos” não percebe suas inverdades: isso é reacionarismo acadêmico.

Para manter a boa vida, a classe dita ociosa precisa agir, não ficar sentada. O trabalho forçado dos serviçais exige coação; se não, logo seria interrompido. A quem interessa a imagem 
de que os escravos trabalham direito, sem reclamar? Assim querem os senhores. Eles não ficam apenas se iludindo com aparências, procuram ver o que se passa, para controlar a situação. A eles interessa que se acredite que o Sol representa um Deus, um Sumo Bem, um princípio absoluto superior à verdade. Esta acaba se tornando apenas adequação à sua vontade.

Poder é também monopólio da informação. Por que os escravos iriam voltar à caverna se podem ir lá fora, onde não tem ninguém, para continuar servindo? Na lógica do mito, eles servem porque querem servir, não porque são obrigados. Essa é uma lógica senhorial, não deles. Na prática, de escravos atarefados dia e noite não se pode esperar que tenham lazer para produzir arte, estudar filosofia e ciências, mas isso não é causado por seu DNA e sim pela espoliação em que vivem. Entre eles podem surgir talentos iguais ou até superiores aos dos ociosos. Estes não são apenas ociosos: ao menos uma parte deles age, organiza o corpo social, mantém a ordem vigente. Não se pode confiar na narrativa de Platão como parâmetro absoluto: há furos demais entre a imagem e a argumentação.

\section{LEITURA ALTERNATIVA}

Se a leitura do "mito da caverna" se revela ideológica e incoerente como texto social, resta buscar ler o texto como parábola, como narrativa alegórica. $O$ que há de importante aí? Tudo é determinado pelo percurso do "filósofo", ele é o centro da atenção, o que ele faz é mais importante do que o fazer de todos os demais. Então é preciso ver o que ele significa.
No primeiro gesto, de se livrar das cadeias, ele iria olhar em torno e começar a entender o teatro encenado dentro da caverna. Não se conta isso. Ele iria, portanto, perceber a fogueira e a projeção das sombras a partir delas. Ele iria ver que tudo é projeção de sujeitos. Quando ele saísse e visse a grande fogueira lá fora, o Sol, ele iria se contaminar pela crença da própria superioridade, de ver aquilo que supõe ver. Ele vê como vê porque crê ser o iluminado, aquele que recebe a projeção da luz e discerne como as coisas efetivamente são. Ele não viu o que precisava ver e acha que já viu tudo.

O fogo é um símbolo do espírito humano. $\mathrm{Na}$ mitologia judaica, Deus aparece como sarça ardente; na grega, Apolo, o deus solar, é também o patrono das artes e dos sonhos; na mitologia cristã, o Espírito Santo aparece como línguas de fogo; no poema de Schiller, Die Glocken (Os sinos), fala-se de "Götterfunken" de centelhas divinas que caracterizam o diferencial humano. Em Platão, mais de uma vez Sócrates fala do "daimon”, esse espírito que toma conta dele e o induz a fazer filosofia (como poderia levar outros a fazer arte).

Quando se toma essa história da caverna como mito, ela se torna uma crença da qual não se duvida. Como nós, porém, não cremos nos deuses e em instituições como a aristocracia hereditária e a escravidão, não precisamos acreditar no que seus pensadores pregavam. A Grécia antiga é barbárie. Não pode mais ser modelo para nós. Temos de desconfiar do que diz. Ao tomar a caverna como parábola, devemos nos abster da postura de rabinos, padres e pastores. Na parábola do Bom Samaritano, a proposta de dividir o manto em dois ignora que as duas metades vão se deparar 
com novas carências, o que vai levar a divisões sucessivas: e com um confete não há muito o que tapar...

O que significa ler ceticamente a parábola desse filósofo da montanha? Ele acha que é o único a ver o sol e sair da caverna. Os que trabalham também tem esse contato, ainda que não seja validado.

O que significa ler ceticamente essa parábola? O primeiro passo, vindo do desassossego de quem não aceita a escravidão, é olhar em torno e tentar entender o mundo como ele é. Faz isso o aristocrático? Não, ele não toma conhecimento dos escravos, não se preocupa em libertá-los, ainda que eles mais precisem de libertação do que os ociosos. Pouco percebe, no entanto, que há uma fogueira e sombras projetadas na parede, ou seja, pouco percebe as aparências como aparências. Se não percebe a aparência como aparência, não percebe a essência como essência. Ele não quer a desconstrução ideológica da opressão. Gosta dela, ela lhe é vantajosa.

Ele não se preocupa com a fogueira interna, a única que lhe restaria para ver algo, pois se supõe predestinado a contemplar a grandeza do Sol, único objeto digno de sua contemplação. Acha que conhecer é estar iluminado pelo alto, pelo poder de que faz parte. Ele se crê iluminado porque se vê como iluminado, dileto filho do divino. Ele é tanto mais arrogante quanto mais ignorante; tanto mais prepotente quanto mais conivente.

Sob a aparência de se preocupar com o mundo, esse filósofo é um alienado: só vale para ele o mundo iluminado lá de fora, aquele mundo que quem vive na caverna não pode, oficialmente, contemplar. O "illuminati" acha que pode ditar leis, pois só ele sabe como as coisas são, diz ele. Aquilo que os trabalhadores e artistas viram, isso não conta: para ele, eles não têm nada a dizer. Onde parece estar sua força reside sua fraqueza. Ele sempre parece falar em nome de algo superior, mas é mais soberbo do que elevado.

Se em vez de tomarmos, então, a caverna como moradia coletiva, como síntese da sociedade escravista grega, se em vez de tomarmos tudo como um templo ou uma academia presidida por um deus, nós a virmos como projeção de uma interioridade psíquica, como uma biografia espiritual, como um percurso de formação? O que temos aí é a parábola de alguém que começa a ver as coisas e instituições do seu meio e do seu tempo de um modo diferenciado, em contrapartida ao modo dominante. Ao olhar ao redor de modo inconformista, ele começaria a enxergar. Até então ele tinha olhos para não ver. Como Édipo, enquanto olhos tinha, não via: quando passasse a encarar a realidade, ele poderia se desfazer dos hábitos de ver.

Ao ver de outro modo, ele passaria a agir de modo diferenciado. Não ficaria do modo conformado, iria se voltar para outros companheiros, para outros lugares. Se ele fosse aquele que nasce com mais agilidade mental e, por isso, é invejado, correndo o risco de ser morto por aqueles que estão ao seu redor, seu risco não decorreria apenas da inveja, e sim da crítica ideológica, da tensão política. Quem representa o futuro, pode ficar sem presença no presente, pode se tornar mero passado, e um passado esquecido. Quem se mete na política corre o risco de ser morto. 
Quem enxergar mais que os outros não deve contar o que vê a mais se quiser sobreviver. Ao se negar a palavra, ao fingir um percurso externo, ele mesmo se aniquila. O herói antecipa o futuro, ele é aquele que veio cedo demais para o seu tempo. Somente se torna herói, porém, aquele mártir atrás do qual todo um exército vem marchando; se não, ele não apenas é esquecido, mas é difamado quando lembrado.

Se o escravo e o artista precisam sair da caverna para exercer suas funções, por que ainda retornam? Por que o filósofo, estando lá fora, não vai pescar e cuidar de sua vida, em vez de voltar e se esgoelar com quem não quer se incomodar com ele por estar todo acomodado? Ele quer que se vejam as sombras na parede como sombras, mas não se preocupa com as sombras humanas que circulam em trabalho serviçal, escravos reduzidos a sobras de gente, como são sobras também os ociosos que nada mais fazem do que consumir, aquele que se aposentam antes mesmo de começar a fazer algo.

\section{INTERMEZZO POÉTICO}

O libertador não quer libertar. Ele é como os "pais da pátria" americana, que declararam $a$ independência com liberdades e mantiveram a escravidão; é como os inconfidentes mineiros, donos de escravos a proclamar o "libertas quae sera tamen"; é como os proclamadores da independência das colônias ibéricas que mantiveram suas fazendas e seus escravos. Assim é fácil. 0 que ganharia o filósofo libertador além da chance de levar surras? Ganha a esperança de se tornar governante. Como vai fazer isso, porém, se não parece ser aceito pelos membros de sua classe e, menos ainda, pelos trabalhadores mergulhados em suas ocupações? Ou ele só finge que tenta libertar os companheiros, enquanto não liberta a quem mais precisa?

Ele parece um gauche. Drummond disse de si que uma entidade lhe havia dito "vá ser gauche na vida”. Isso significou para ele, na prática, ser chefe de gabinete de Capanema, ministro da Educação e Saúde do governo fascista de Vargas. Assim é fácil. Dizer que é, sem ser. Nessa moda de ser gauche, não é gauche quem serve à extrema-direita.

Não é, no entanto, tão absurda a versão de Drummond. Ela corresponde ao que a Igreja Católica fez, ao que a Luterana fez e ao que fazem todas as outras. Não só as igrejas. Os monarcas, se não se viam como rei-sol coroado, como Louis XIV, ao menos recebiam santos óleos que lhes permitiam penetrar no reino do além, transcender seu corpo. Não só os monarcas. Também os líderes ditos democratas regem não em nome de uma oligarquia que lhes dá abrigo e força, mas em nome de princípios superiores, como justiça social, Estado de Direito, representação democrática, equilíbrio de forças, sensatez fiscal.

E os artistas então, será que eles se enxergam como meros coadjuvantes do sistema, destinados a entreter a classe dominante e, na melhor das hipóteses, despertarem um sorriso e fazerem os escravos modernos recuperar suas forças, para continuar a trabalhar do mesmo jeito, dia após dia, ano após ano? A esperança se tornou apenas uma fugaz mensageira entre 0 aquém e o além, ela não tem mais deuses que a usem para enviar mensagens de salvação, palavras sábias. Tem-se o gosto de fel na boca. 
Daí é ensinado que se está a caminho da salvação, pois é divino sentir fel na boca. Esse fel tem o gosto da cicuta. Cabe perguntar ao carrasco o que melhor fazer quando o veneno começar a fazer efeito, e ele dirá que o melhor é caminhar um pouco para lá e para cá, continuar a conversar com os discípulos e amigos, até que o corpo cansado peça repouso e nada mais se possa fazer.

De Paul Celan é o poema "Lembrança da França":

Recorda comigo: o céu de Paris, o imenso narciso do outono...

Compramos corações na florista: eram azuis e floresceram na água. Começou a chover em nosso recanto, e veio o nosso vizinho, Monsieur Le Songe, franzino homenzinho.

Nós jogamos cartas, perdi os olhos da cara: tu me emprestaste o teu cabelo, eu o perdi, ele nos derrotou.

Ele saiu pela porta, a chuva o seguiu.

Nós estávamos mortos e podíamos respirar. ${ }^{4}$

Aqui ocorre algo pior: a utopia, o sonho, o mundo além, embora sejam apenas um franzino homenzinho, faz com que percamos o jogo. Em vez de ser nossa distinção, é nossa maldição. Em vez de salvação, morte. Não somos mais, como no dito de Fernando Pessoa, "cadáveres adiados que procriam": embora possamos respirar, embora possamos fingir que estamos vivenciando coisas, estamos mortos. Talvez o modo mais simples de ler isso seja supor que se está morto para um relacionamento.

O que significa aí emprestar o cabelo, perder o cabelo? No poema "Com a mão cheia de horas", que se sabe ter sido inspirado no relacionamento de Celan com a poetisa suíça Ingeborg Bachmann, que era loira e cujo pai foi nazista, ele diz no fim: "A folhagem dos anos é castanha, o teu cabelo não". ${ }^{5}$ O judeu se distancia de quem não tiver a sua própria história; ser judeu não é, no entanto, aí garantia de proximidade, de um relacionamento que funcione.

O problema não é pessoal, e sim existencial. Inverte-se o platonismo: ter conseguido perceber como as coisas realmente são leva a um duplo exílio: exilado dentro da caverna, por ter vislumbrado um mundo melhor, onde seria mais adequado viver; exilado dentro da caverna, pela lembrança opressiva do que nela se passa e a necessidade de abandonar o mundo melhor para retornar à desgraça de onde se saiu por algum tempo. Esse é o drama hoje, por exemplo, não só de milhões que procuram sair do mundo subdesenvolvido para ir viver em países desenvolvidos, mas do número muito maior daqueles que gostariam de estar fora e não vão poder sair. A globalização ativa e destrói esperanças. Quem está onde está gostaria de estar num lugar melhor; quem está numa situação melhor teme que ela lhe seja tomada. No trânsito e na transição, todos se tornam infelizes.

O sonho é Monsieur Le Songe, um elemento estranho, que não nos traz para perto o que em nós está e nos é ignoto: ele é perda e estranheza, um jogo em que se tenta ganhar e, quanto mais se tenta, mais se perde. Narciso é uma flor, uma droga, um remédio, um perfil psicológico e a síntese do céu de Paris, que tudo encobre e

4 Kothe, Flávio R. A poesia hermética de Paul Celan, Brasília, Edunb, 2016, p. 51.

5 Idem, p. 43. 
recobre. O lugar ideal de se morar não é garantia de felicidade. Não há paraíso, no entanto se está exilado dele. Não há um saber absoluto, mas somente ele vale.

Somos sombras de nós mesmos, apenas uma pálida citação do que poderíamos ter sido se tivéssemos vivido fora da caverna. $O$ sonho nos lembra sempre o que olvidamos no dia a dia, aquilo que nos machucou, aquilo que lembre a fragilidade de nossa pele. Jogamos como se tivéssemos chance de ganhar. O poema lírico lembra a perda do amor. A duplicação metafísica do mundo nos deixou exilados na Terra, exilados de nós mesmos. Não acreditamos mais num "mundo das ideias verdadeiro", temos de nos conformar em viver à sombra de nós mesmos, pálidos palhaços empalhados, ausência de real vida a fingir que vivenciamos o que mais aspiramos.

A filosofia procura superar a duplicação metafísica e acabamos sem nenhum mundo verdadeiro. Somos ceguetas. Cegos guiam cegos, todos falam, raramente alguém diz algo que se aproveite. Quando nos entregamos às sombras da televisão, do cinema, do bate papo, mora conosco a inquietação de estarmos enganando a nós e a outros, encenando um teatro como se ele fosse real.

Nesse mundo de ficção, o que pode nos redimir um pouco é a ficção: ela ao menos não finge ser real. Construir fábulas constitui nosso último reduto. Quando conseguimos, finalmente, dizer algo válido, o poder do meio se impõe e o texto não é divulgado. Aquilo que mais vende, vende mais por ter menos a dizer. Todos correm atrás de números, como se a essência do mundo fosse numérica. Vivemos a grande farsa postulada como "organização formal do projeto de pesquisa”, "relatórios”, “ciência”. Só nos resta o silêncio como se ele pudesse abrigar mais verdades do que a palavra que se torna palavrório. Calar é o melhor modo de falar.

Hoje não podemos mais salvar nem a nós mesmos, menos ainda a outros e ao mundo inteiro! Não temos autorização nem autoridade. Ainda que vejamos muita coisa errada, não há um mundo certo a partir do qual julgar. Somos a perda das nossas melhores alternativas, somos apenas a alternativa que restou. Ela é o nada do que poderia ter sido. Resta o nada numa vida feita de perdas. Somos o espaço em que o nada institui seu discurso. Assim acaba o nosso tempo, não acaba o tempo que conosco acaba.

\section{O RETORNO DOS QUE NÃO FORAM}

A caverna de Platão é a cabeça de Platão, a mentalidade de uma aristocracia escravista. Nela, os escravos apenas procuram, sem reclamar, servir a seus senhores: não há comandos nem punições. Eles não são propriamente gente. Não há espírito neles a ser salvo. Com nenhum deles conversa o filósofo que diz que se liberta. Ele pode pretender libertar todo o mundo, menos os escravos da escravidão. 0 mais evidente ele não vê, porque não quer ver.

Em nenhum momento Heidegger toca nessa questão crucial. Como em toda a recepção apolínia da Grécia, esse problema não existe, como aliás também não existe para Nietzsche, mesmo quando defende a existência do dionisíaco: escravos são, no máximo, um mal necessário para que se produza arte e filosofia, como se elas não se contaminassem por essa 
condição de produção. O próprio Hegel escapou dessa questão, na parte final da introdução à História da Filosofia, dizendo que sabia que a escravidão tinha sido a condição possibilitadora para que uma minoria pudesse se dedicar a filosofar: ele teve de reconhecer a existência do problema, mas não se dedicou a examinar como isso poderia ter afetado a estrutura do pensamento. Depois dele, o problema como que evapora da filosofia alemã. Mesmo Marx fica restrito à observação superficial de que a Grécia teria sido a infância da humanidade, como se traumas de infância não tivessem consequências na vida adulta.

A caverna platônica não é um lugar qualquer. Ela é a base da distinção entre verdade e mentira, entre episteme e doxa. Ela é o lugar onde se pergunta se o conhecimento liberta. Se ela própria é ideologia de uma classe, não pode ser fundamento do conhecimento que transcenda as classes. Não é um sujeito transcendental absoluto. Uma visão parcial e falsa não pode ser o fundamento para se ver tudo e todos por todos os tempos.
Como pode Heidegger, definir o ser humano a partir daquele membro da classe ociosa que finge que se libertou e que somente ele saiu da caverna? Ele nega as evidências. É um pregador, um escravagista, um político oligarca, não $O$ Homem. Cada classe marca o modo de ser e de pensar de uma época. Ela define por si o que seja o homem em geral, só que ele não é apenas isso que ela diz.

A perspectiva de que possa haver uma igualdade básica dos humanos não seria apenas uma retroprojeção anacrônica. Sófocles já havia proposto, na peça Ajax, que os homens são iguais diante da doença grave e da morte: passam a depender de outros. Poderia ter acrescentado que são igualmente dependentes quando nascem e nos seus primeiros anos de vida: se não tiverem ajuda de outros, morrem. Eurípides também havia dito, em As troianas, que a escravidão vilaniza, sendo indigna de quem nasceu livre (ainda que tenha cuidado de não dizer que todo homem deveria nascer livre: não dizer não impediu que tivesse de fugir de Atenas para salvar a pele). A visão idealizada, apolínea, da Grécia é macabra. 